\title{
PENINGKATAN KETERAMPILAN MENULIS TEKS BERITA MELALUI PENGGUNAAN MEDIA VIDEO PADA SISWA SMP
}

\author{
Heddi Marlina $\mathbf{S}^{\mathbf{1}}$, Sadieli $\mathbf{T}^{\mathbf{1}}$, dan Ramadhan Saleh $\mathrm{L}^{\mathbf{1}}$ \\ ${ }^{1}$ Universitas Prima Indonesia \\ Email: heddymarlina1996@gmail.com
}

\begin{abstract}
Abstrak
Penelitian ini bertujuan untuk meningkatkan keterampilan menulis teks berita melalui penggunaan media video pada siswa kelas VIII-A SMP Swasta Imelda Medan pada tahun pembelajaran 2018/2019. Dalam pembelajaran Bahasa Indonesia, menulis merupakan aspek keterampilan yang harus dikuasai selain aspek keterampilan menulis. Standar kompetensi menulis yang diharapkan dari siswa kelas VIII-A SMP Swasta Imelda Medan pada tahunpembelajaran 2018/2019 adalah mampu menulis kalimat-kalimat dan paragraf dengan baik, menulis karangan sederhana, tanda baca, kosa kata yang semuanya diarahkan untuk menumbuhkan kebiasaan menulis. Pendekatan yang digunakan dalam penelitian ini menggunakan metode Penelitian Tindakan Kelas melalui uji coba ide ke dalam situasi nyata yang diharapkan mampu memperbaiki dan meningkatkan kualitas proses belajar mengajar di skelas. Sehingga dapat disimpulkan bahwa berdasarkan rumusan masalah dan hipotesis tindakan, penggunaan media video dapat meningkatkan kemampuan menulis teks berita siswa kelas VIII-A SMP Swasta Imelda Medan dan hal tersebut dapat membantu guru bidang studi Bahasa Indonesia untuk lebih aktif lagi dalam mengelola kondisi kelas.
\end{abstract}

Kata kunci: Menulis, Teks Berita, Penelitian Tindakan Kelas.

\begin{abstract}
This research is to improve news text writing skills with video media at second grade students of SMP Swasta Imelda Medan in the accademic year 2018/2019. In lessson of Indonesian, writing is an aspect of skills that must be mastered in addition to aspects of writing skills. The standard of writing competences that expected from student of VIII-A class at SMP Swasta Imelda Medan accademic year 2018/2019 is able to write good sentences and paragraphs, write simple essays, punctuation marks, vocabulary all directed to cultivate writing habits. The approximation in this research is uses Classroom Action Research method through trials ideas into real situations that are expected to be able to improve the quality of teaching and learning process in the classroom. So it can be concluded that based on the formulation of the problem and the hypothesis of action, use of video media can improve the ability to write news texts the student of VIII-A class SMP Swasta Imelda Medan and it can help Indonesian language study teachers to be more active in managing classroom conditions.
\end{abstract}

Keywords: Writing, News Text, Classroom Action Research. 


\section{PENDAHULUAN}

Pada hakekatnya belajar Bahasa Indonesia adalah belajar berkomunikasi yang bertujuan untuk meningkatkan keterampilan siswa dalam berkomunikasi dengan Bahasa Indonesia yang dipelajari secara lisan dan tulisan dalam mengungkapkan ide atau gagasan kepada orang lain. Keterampilan menulis menjadi satu diantara kompetensi dasar kemampuan berbahasa. Didalam pembelajaran bahasa Indonesia, terdapat standar kompetensi menyusun teks berita dengan karakteristik teks yang akan dibuat baik secara lisan maupun tulisan pada silabus bahasa Indonesia kelas VIII yang diharapkan mampu mengidentifikasi dan menelaah teks berita untuk mengungkapkan informasi penting dari suatu teks dan media video berita yang dibahas dalam materi pembelajaran. Namun pada kenyataannya, kemampuan menulis teks berita siswa masih tergolong rendah dan dibawah rata-rata, terutama saat mencari unsur-unsur yang terkandung dalam berita.

Video merupakan suatu medium yang sangat efektif untuk membantu proses pembelajaran, baik untuk pembelajaran individu maupun kelompok. Media video juga merupakan bahan ajar noncetak yang kaya informasi dan tuntas karena dapat sampai ke hadapan siswa secara langsung. Hal ini karena karakteristik teknologi video yang dapat menyajikan gambar bergerak pada siswa, di samping suara yang menyertainya. Dengan demikian, siswa merasa seperti berada di suatu tempat yang sama dengan program yang ditayangkan video.

Kelebihan dari model pembelajaran teks berita melalui media video adalah memberikan kesempatan pada siswa untuk dapat maju terus sesuai dengan potensi yang dimiliki siswa sehingga terlibat dan aktif dalam proses Kegiatan Belajar Mengajar (KBM), sehingga siswa dapat berpikir kritis dan kreatif dalam mengumpulkan data, memahami isu dan memecahkan masalah dan guru dapat lebih kreatif. Pembelajaran lebih menyenangkan dan tidak membosankan, membantu siswa bekerja dengan efektif. Hasil akhir media ini peserta didik menjadi lebih aktif dan kreatif.

Menurut Heinich (2012:2), media merupakan bentuk jamak dari kata medium. Medium dapat didefinisikan sebagai perantara atau pengantar terjadinya komunikasi dari pengirim menuju penerima. Berdasarkan definisi tersebut dapat dikatakan bahwa media pembelajaran merupakan sarana pelantara dalam proses pembelajaran.

Pengertian media video menurut Jarome Bruner (2012:5) yaitu segala sesuatu yang memungkinkan sinyal audio dapat dikombinasikan dengan gambar bergerak. Program video dapat bermanfaatdalam program pembelajaran sehingga memudahkan siswa untuk berpikir secara cepat. Video bersifat interaktif tutorial melalui visualisasi. Peserta didik dapat secara interaktif mengikuti kegiatan praktik sesuai dengan yang diajarkan dalam video.

Daryanto (2010:2) mengungkapakan bahwa video merupakan suatu medium yang sangat efektif untuk membantu proses pembelajaran, baik untuk pembelajaran masal, individual, maupun berkelompok. Pada pembelajaran yang bersifat masal (mass instruction), manfaat kaset video sangat nyata. Adapun kaarakteristik video yaitu:

1. Mengatasi keterbatasan jarak dan waktu.

2. Video dapat diulangi bila perlu untuk menambah kejelasan.

3. Pesan yang disampaikannya cepat dan mudah diingat.

4. Mengembangkan pikiran dan pendapat para siswa.

5. Mengembangkan imajinasi peserta didik.

6. Memperjelas hal-hal yang abstrak dan memberikan gambaran yang lebih realistik. 
7. Sangat baik menjelaskan suatu proses dan keterampilan: mampu menunjukkan ransangan yang sesuai dengan tujuan dan respon yang diharapkan dari siswa.

8. Menumbuhkan minat dan motivasi belajar.

Marwonto Daiman (2014:5) menjelaskan bahwa menulis adalah mengungkapkan ide atau gagasannya dalam bentuk karangan secara leluasa dalam hal ini menulis itu membutuhkan skemata yang luas sehingga sipenulis mampu menuangkan ide, gagasan, pendapatnya dengan mudah dan lancar. Dengan demikian, menulis merupakan suatu cara menyampaikan pikiran atau perasaan dalam bentuk tulisan. Dalam hal ini, struktur bahasa dan kosakata akan mempengaruhi pesan yang disampaikan penulis dan dapat diterima dengan baik oleh pembaca.

Menurut pendapat Saleh Abbas (2009:125), keterampilan menulis adalah kemampuan mengungkapkan gagasan, pendapat dan perasaan kepada pihak lain dengan melalui bahasa tulis. Ketepatan pengungkapan gagasan harus didukung dengan ketepatan bahasa yang digunakan, kosakata dan gramatikal dan penggunaan ejaan.

Suparno dan Mohammad Yunus (2008 : 37) mengemukakan bahwa tujuan menulis adalah sebagai berikut:

1. Menjadikan pembaca ikut berpikir dan bernalarMembuat pembaca tahu tentang hal yang diberitakan.

2. Menjadikan pembaca beropini.

3. Menjadikan pembaca mengerti.

4. Membuat pembaca terpersuasi oleh isi karangan.

5. Membuat pembaca senang dengan menghayati nilai-nilai yang dikemukakan seperti nilai kebenaran, nilai agama, nilai pendidikan, nilai sosial, nilai moral, nilai kemanusiaan dan nilai estetika.

Menurut Willard C. Bleyer (2009:8), Teks Berita adalah suatu kejadian aktual yang diperoleh wartawan untuk dimuat dalam surat kabar karena menarik atau mempunyai makna bagi pembaca. Sedangkan menurut William S. Maulsby (2008:7), Berita adalah suatu penuturan secara benar dan tidak memihak fakta-fakta yang mempunyai arti penting dan baru terjadi yang dapat menarik perhatian para pembaca surat kabar yang memuat berita tersebut.

Unsur penting yang harus terkandung dalam Teks Berita menurut Dr. E. Kosasih (2012:102-103) adalah:

1. Apa (yang terjadi dalam suatu peristiwa?)

2. Siapa (yang terlibat dalamperistiwa itu?)

3. Dimana (terjadi peristiwa itu?)

4. Kapan (terjadinya peristiwa itu?)

5. Mengapa (terjadi peristiwa itu?)

6. Bagaimana (terjadinya peritiwa itu?)

\section{METODE}

Metode atau jenis penelitian yang digunakan dalam penelitian ini adalah Tindakan Kelas (Classroom Action Research). Penelitian tindakan kelas merupakan salah satu cara untuk memperbaiki dan meningkatkan kualitas program sekolah secara keseluruhan. Penelitian tindakan kelas yaitu penekanan melalui uji coba ide ke dalam praktek yang diharapkan kegiatan tersebut mampu memperbaiki dan meningkatkan kualitas proses belajar mengajar di kelas.

Penelitian ini diawali dengan tahap indentifikasi masalah, pengajuan judul, penyusunan proposal sampai hasil penelitian. Waktu penelitian ini merupakan rincian kegiatan yang dilakukan untuk memenuhi syarat dan memperoleh gelar sarjana pendidika. Penelitian ini 
dimulai dari bulan april 2019 diperkirakan selasai pada bulan april 2019. Subjek penelitian ini adalah siswa kelas VIII-A SMP Swasta Imelda Medan 2018/2019 yang berjumlah 34 siswa, dengan siswa 19 laki-laki dan 15 siswa perempuan. Karena ditemukan permasalahan mengenai kemampuan menulis sehingga pengambilan sampel sebagai subjek penelitian dilakukan dengan sampel bertujuan (purposive sample).

Penelitian ini memiliki beberapa tahap pelaksanan tindakan dengan siklus sebagaimana setiap siklusnya mempunyai empat tahap pelaksaan yang digambarkan pada diagram alur berikut:

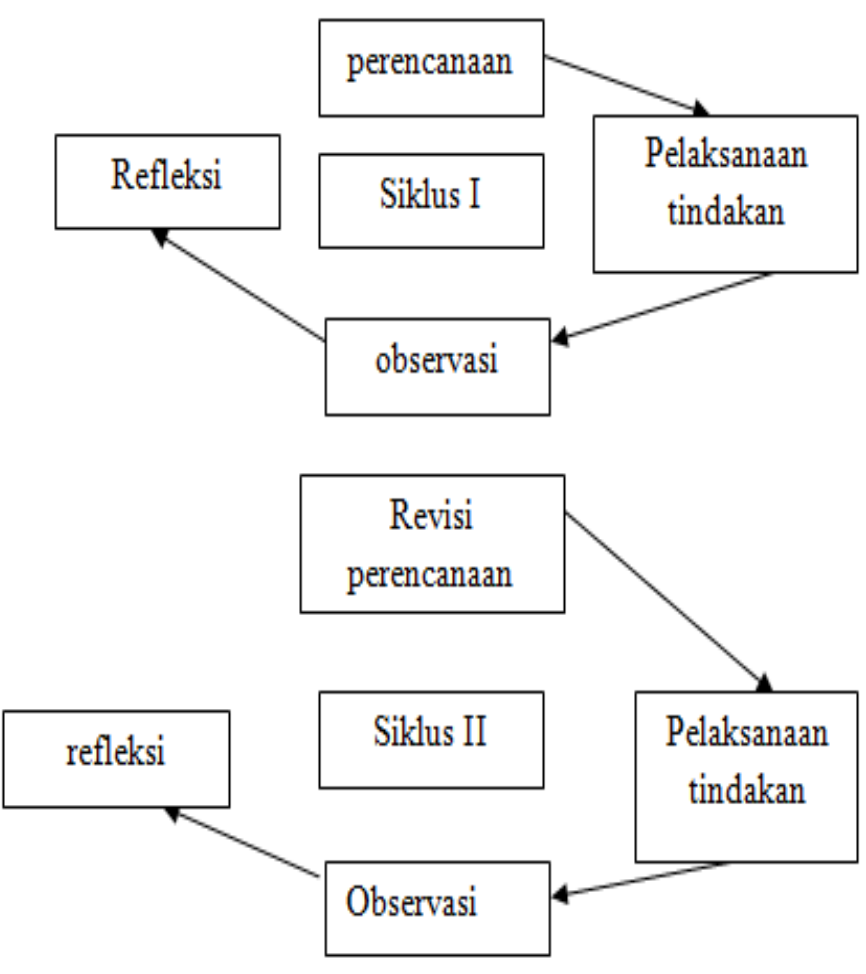

Gambar 1

Siklus Penelitian Tindakan kelas Kemmis dan Mc Taggart (Arikunto, 2014 :137)

Teknik pengumpulan data yang digunakan dalam penelitian ini yaitu wawancara, observasi, tes, dan dokumentasi. Teknik analisis data yang dilakukan adalah dengan menggunakan rumus yang dipakai untuk menghitung nilai rata-rata yaitu:

$$
x \frac{\sum X}{\sum N}
$$

Keterangan :

$x \quad:$ menyatakan nilai rata-rata

$\sum X \quad:$ menyatakan jumlah semua nilai siswa.

$\sum \mathrm{N} \quad$ : menyatakan jumlah siswa.

Untuk menghitung persentase ketuntasan belajar kemampuan menulis teks eksplanasi siswa, digunakan rumus: 


$$
P=\frac{\sum \text { siswa yang tuntas belajar }}{\sum \text { siswa }} \times 100 \%
$$

Untuk mengetahui ketuntasan aktivitas belajar siswa digunakan rumus:

$$
P=\frac{\sum \text { skor perolehan keaktifan siswa }}{\sum \text { skor maksimal keaktifan }} \times 100 \%
$$

Analisis ini dilakukan pada saat tahapan refleksi. Hasil ini digunakan sebagai bahan refleksi untuk melakukan perencanaan lanjut dalam siklus selanjutnya.

\section{HASIL PENELITIAN DAN PEMBAHASAN}

\section{Hasil Penelitian}

Penelitian dilaksanakan di kelas VIII-A SMP Swasta Imelda Medan dengan jumlah 34 siswa yang terdiri dari 19 siswa laki-laki dan 15 siswa perempuan. Hasil penelitian ini diperoleh dari hasil tindakan siklus I dan siklus II yang terdapat pada hasil tes dan nontes. Hasil tes tindakan siklus I dan siklus II merupakan hasil kemampuan menulis teks berita siswa sesudah menerapkan media pembelajaran video. Adapun hasil penelitian ini mencakup tiga hal berikut:

1. Bagaimana proses pembelajaran keterampilan menulis teks berita melalui penggunaan media video pada siswa kelas VIII-A SMP Swasta Imelda Medan

2. Bagaimanakah hasil pembelajaran peningkatan keterampilan menulis teks berita melauli penggunaan media video pada siswa kelas VIII-A SMP Swasta Imelda Medan

3. peningkatan hasil pembelajaran keterampilan menulis teks berita melalui penggunan media video pada siswa kelas VIII-A SMP Swasta Imelda Medan.

Tahapan tindakan pembelajaran siklus I merupakan tindakan awal untuk memperbaiki permasalahan yang terdapat di kelas yaitu siswa kelas VIII-A SMP Swasta Imelda Medan tidak antusias untuk membaca sumber belajar yang digunakan (berupa buku dan koran). Pada pembelajaran menulis teks berita siklus I ini menerapkan media video yang terdiri dari hasil tes dan nontes. Kedua hasil penelitian tersebut meliputi nilai tes kemampuan menulis teks berita dan kegiatan pembelajaran guru beserta siswa selama berlangsungnya proses pembelajaran di kelas. Lembar pengamatan keaktifan siswa sikus I digambarkan pada Tabel 1. 
Tabel 1

Lembar Pengamatan Keaktifan Siswa Siklus I

\begin{tabular}{|c|c|c|c|c|c|c|}
\hline \multirow{2}{*}{ No. } & \multirow{2}{*}{$\begin{array}{l}\text { Aspek yang } \\
\text { diperoleh }\end{array}$} & \multicolumn{4}{|c|}{$\begin{array}{c}\text { Jumlah Responden berdasarkan Hasil } \\
\text { Pengamatan }\end{array}$} & \multirow[b]{2}{*}{$\begin{array}{c}\text { Jumlah Keseluruhan } \\
\text { Siswa }\end{array}$} \\
\hline & & $\begin{array}{c}\text { Amat } \\
\text { baik } \\
\text { (4) }\end{array}$ & $\begin{array}{c}\text { Baik } \\
\text { (3) }\end{array}$ & $\begin{array}{c}\text { Sedang } \\
\text { (2) }\end{array}$ & $\begin{array}{c}\text { Kurang } \\
\text { (1) }\end{array}$ & \\
\hline 1 & Kesiapan Siswa & 2 Siswa & 25 Siswa & 7 Siswa & - & 34 Siswa \\
\hline 2 & Antusian Siswa & 5 Siswa & 29 Siswa & - & - & 34 Siswa \\
\hline 3 & $\begin{array}{l}\text { Kreatifitas } \\
\text { Siswa }\end{array}$ & 2 Siswa & 19 Siswa & 13 Siswa & - & 34 Siswa \\
\hline 4 & $\begin{array}{l}\text { Ketekunan } \\
\text { Siswa }\end{array}$ & - & 34 Siswa & - & - & 34 Siswa \\
\hline 5 & Inisiatif Siswa & - & 17 Siswa & 17 Siswa & - & 34 Siswa \\
\hline
\end{tabular}

Tahap pembelajaran pada siklus II dilakukan karena hasil tes kemampuan menulis teks berita siklus I belum mencapai standar target kriteria ketuntasan minimal pelajaran Bahasa Indonesia yaitu 75. Pelaksanaan siklus II ini masih menerapkan media video dengan segala perbaikan untuk mengatasi masalah yang ada pada siklus I. Siklus II dipersiapkan dan direncanakan lebih matang karena siklus ini merupakan upaya untuk meningkatkan hasil belajar siswa dalam meningkatkan kemampuan menulis teks berita siswa menjadi lebih baik dari pada tindakan pembelajaran siklus I. Lembar pengamatan keaktifan siswa siklus II digambarkan pada Tabel 2. 
Tabel 2

Lembar Pengamatan Keaktifan Siswa Siklus II

\begin{tabular}{|c|c|c|c|c|c|c|}
\hline \multirow{2}{*}{ No. } & \multirow[b]{2}{*}{$\begin{array}{l}\text { Aspek yang } \\
\text { diperoleh }\end{array}$} & \multicolumn{4}{|c|}{$\begin{array}{c}\text { Jumlah Responden berdasarkan Hasil } \\
\text { Pengamatan }\end{array}$} & \multirow[b]{2}{*}{$\begin{array}{c}\text { Jumlah } \\
\text { Keseluruhan } \\
\text { Siswa }\end{array}$} \\
\hline & & $\begin{array}{c}\text { Amat } \\
\text { baik } \\
\text { (4) }\end{array}$ & $\begin{array}{l}\text { Baik } \\
\text { (3) }\end{array}$ & $\begin{array}{c}\text { Sedang } \\
\text { (2) }\end{array}$ & $\begin{array}{c}\text { Kurang } \\
\text { (1) }\end{array}$ & \\
\hline 1 & Kesiapan Siswa & $\begin{array}{l}18 \\
\text { Siswa }\end{array}$ & 8 Siswa & 8 Siswa & - & 34 Siswa \\
\hline 2 & Antusian Siswa & $\begin{array}{l}34 \\
\text { Siswa }\end{array}$ & - & - & - & 34 Siswa \\
\hline 3 & Kreatifitas Siswa & 9 Siswa & 15 Siswa & 10 Siswa & - & 34 Siswa \\
\hline 4 & Ketekunan Siswa & - & 34 Siswa & - & - & 34 Siswa \\
\hline 5 & Inisiatif Siswa & - & 34 Siswa & - & - & 34 Siswa \\
\hline
\end{tabular}

Hasil tes berdasarkan data yang diperoleh pembelajaran siklus I meningkatkan kemampuan dalam menulis teks berita Potret Pendidikn di Indonesia disaat menggunakan media video pembelajaran berita dapat dilihat dalam Tabel 3. 
Tabel 3

Hasil Tes Kemampuan Menulis Teks Berita Potret Pendidikan di Indonesia Siklus I

\begin{tabular}{|c|c|c|c|c|}
\hline \multirow{2}{*}{ Nama } & \multirow{2}{*}{ L/P } & \multirow{2}{*}{ Nilai Tes Silluus I } & \multicolumn{2}{|c|}{ Ketuntasan Belajar } \\
\hline & & & Tuntas & Tidale Tuntas \\
\hline Rl & L & 70 & $\checkmark$ & \\
\hline $\mathrm{R} 2$ & $\mathrm{P}$ & 62 & & $\checkmark$ \\
\hline R3 & I & 61 & & $\checkmark$ \\
\hline R4 & I & 80 & $\checkmark$ & \\
\hline R5 & I & 63 & & $\checkmark$ \\
\hline R6 & $\mathrm{P}$ & 62 & & $\checkmark$ \\
\hline R7 & $\mathrm{p}$ & 60 & & $\checkmark$ \\
\hline RS & P & 60 & & $\checkmark$ \\
\hline $\mathrm{Rg}$ & P & 70 & $\checkmark$ & \\
\hline R10 & P & 70 & $\checkmark$ & \\
\hline R11 & I & 75 & $\checkmark$ & \\
\hline R12 & I & 60 & & $\checkmark$ \\
\hline R13 & I & 63 & & $\checkmark$ \\
\hline R14 & I & 61 & & $\checkmark$ \\
\hline R15 & I & 61 & & $\checkmark$ \\
\hline R16 & I & 71 & $\checkmark$ & \\
\hline R1? & I & 62 & & $\checkmark$ \\
\hline R18 & $\mathrm{P}$ & 80 & $\checkmark$ & \\
\hline R19 & I & 70 & $\checkmark$ & \\
\hline R20 & I & 61 & & $\checkmark$ \\
\hline R21 & I & 80 & $\checkmark$ & \\
\hline $\mathrm{R} 22$ & I & 70 & $\checkmark$ & \\
\hline R23 & $\mathrm{P}$ & 62 & & $\checkmark$ \\
\hline R24 & I & 85 & $\checkmark$ & \\
\hline $\mathrm{R} 25$ & I & 71 & $\checkmark$ & \\
\hline R26 & I & 70 & $\checkmark$ & \\
\hline R27 & $\mathrm{p}$ & 70 & $\checkmark$ & \\
\hline R28 & $\mathrm{p}$ & 87 & $\checkmark$ & \\
\hline R29 & $\mathrm{p}$ & 70 & $\checkmark$ & \\
\hline R30 & P & 70 & $\checkmark$ & \\
\hline R31 & P & 83 & $\checkmark$ & \\
\hline R32 & $\mathrm{p}$ & 70 & $\checkmark$ & \\
\hline R33 & $\mathrm{P}$ & 80 & $\checkmark$ & \\
\hline R34 & I & 71 & $\checkmark$ & \\
\hline \multicolumn{2}{|c|}{ Jumlah Nilai } & \multicolumn{3}{|c|}{2361} \\
\hline \multicolumn{2}{|c|}{ Rata-rata Kelas } & \multicolumn{3}{|c|}{69,4} \\
\hline
\end{tabular}

Keterangan:
L: Laki-laki
P: Perempuan

Berdasarkan data hasil penelitian siklus I tersebut, kemampuan menulis teks berita siswa kelas VIII-A mendapat 21 siswa yang tuntas dan 13 siswa yang belum tuntas dalam pembelajaran teks berita Potret pendidikan di Indonesia. Dari penilaian hasil data tersebut dinyatakan bahwa kemampuan menulis teks berita siswa belum memuaskan karena belum 
sesuai dengan keberhasilan target pada KKM (Kriteria Ketuntasan Minimal) $\geq 75$ dan KKK (Kriteria Ketuntasan Klasikal) $\geq 75 \%$ dari jumlah siswa.

Adapun rangkuman hasil data pelaksanaan observasi pada siklus I yang berupa hasil penilaian tes awal kemampuan menulis sebuah teks berita terangkum dalam Tabel 4.

Tabel 4

Perolehan Nilai Siklus I

Tes Kemampuan Menulis Teks Berita Potret Pendidikan di Indonesia

\begin{tabular}{|c|c|c|}
\hline $\begin{array}{l}\text { Rentang } \\
\text { Nilai }\end{array}$ & Banyak Siswa & $\begin{array}{l}\text { Nilai Presentasi KKK Menulis Teks Berita } \\
\text { Potret Pendidikan di Indonesia }\end{array}$ \\
\hline $90-100$ & - & \\
\hline $80-89$ & 7 & $61,8 \%$ \\
\hline $70-79$ & 14 & Tinggi $(\leq 75 \%)$ \\
\hline$\leq 69$ & 13 & Belajar Siswa, Halaman 44) \\
\hline$\Sigma$ & 34 & \\
\hline
\end{tabular}

Siswa mendapatkan presentase kriteria ketuntasan klasikal 61,8\% pada siklus I karena sebagian siswa dapat memahami cara menulis teks berita berdasarkan teknik penulisan yang telah dipelajari. Akan tetapi, sebagian pendapatnya kedalam tulisannya karena penerapan media pembelajaran video membuat mereka sedikit kewalahan. Maka, dapat disimpulkan nilai presentasi KKK kemampuan menulis masih tergolong rendah.

Berdasarkan analisis dalam bentuk tabel tersebut, peneliti bersama guru mata pelajaran Bahasa Indonesia perlu mengadakan perbaikan proses pembelajaran dengan menyusun tahap perlakuan yang tepat dalam pembelajaran teks berita.

Hasil tes berdasarkan data yang diperoleh pembelajaran siklus II untuk meningkatkan kemampuan menulis teks berita Kasus Dugaan Pengeroyokan Siswi SMP disaat menerapkan media video dalam pembelajaran dapat dilihat dalam Tabel 5. 
Tabel 5

Hasil Tes Kemampuan Menulis Teks Berita Kasus Dugaan Pengeroyokan Siswi SMP Siklus II

\begin{tabular}{|c|c|c|c|c|}
\hline \multirow{2}{*}{ Nama } & \multirow{2}{*}{$L / P$} & \multirow{2}{*}{ Nilai Tes Siklus II } & \multicolumn{2}{|c|}{ Ketuntasan Belajar } \\
\hline & & & Tuntas & Tidalk Tuntas \\
\hline R1 & $\mathrm{L}$ & 70 & $\checkmark$ & \\
\hline R.2 & $\mathrm{P}$ & 83 & $\sqrt{2}$ & \\
\hline R3 & $\mathrm{L}$ & 84 & $\checkmark$ & \\
\hline $\mathrm{R} 4$ & $\mathrm{~L}$ & 69 & & $\bar{r}$ \\
\hline R.5 & L & 66 & & $\checkmark$ \\
\hline R6 & P & 82 & $\checkmark$ & \\
\hline R7 & P & 81 & 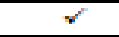 & \\
\hline R8 & P & 73 & $\checkmark$ & \\
\hline R.9 & P & 76 & $\checkmark$ & \\
\hline R.10 & $\mathrm{P}$ & 72 & $\checkmark$ & \\
\hline R11 & $\overline{\mathrm{L}}$ & 79 & $\checkmark$ & \\
\hline R12 & $\mathrm{L}$ & 65 & & $\checkmark$ \\
\hline R13 & L & 72 & 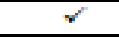 & \\
\hline R.14 & $\mathrm{L}$ & 84 & 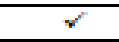 & \\
\hline R.15 & $\mathrm{L}$ & 81 & $\checkmark$ & \\
\hline R.16 & $\overline{\mathrm{L}}$ & 80 & $\checkmark$ & \\
\hline R17 & $\mathrm{L}$ & 85 & $\checkmark$ & \\
\hline R18 & P & 65 & & $\checkmark$ \\
\hline R19 & $\mathrm{L}$ & 77 & $\checkmark$ & \\
\hline R.20 & L & 85 & $\checkmark$ & \\
\hline R.21 & L & 87 & $r$ & \\
\hline R.22 & $\mathrm{L}$ & 84 & $\sqrt{2}$ & \\
\hline R.23 & P & 81 & $\checkmark$ & \\
\hline R.24 & L & 69 & & $\bar{r}$ \\
\hline $\mathrm{R} 25$ & L & 82 & $\checkmark$ & \\
\hline R.26 & L & 69 & & 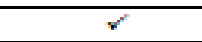 \\
\hline R.27 & P & 78 & $\bar{r}$ & \\
\hline R.28 & P & 85 & $\bar{r}$ & \\
\hline R.29 & $\mathrm{P}$ & 89 & $\checkmark$ & \\
\hline R.30 & P & 66 & & 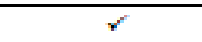 \\
\hline R.31 & P & 85 & $\checkmark$ & \\
\hline R.32 & P & 65 & & $\checkmark$ \\
\hline R.33 & P & 85 & $r$ & \\
\hline R34 & L & 86 & $\checkmark$ & \\
\hline \multicolumn{2}{|c|}{ Jumlsh Nilsi } & \multicolumn{3}{|c|}{2640} \\
\hline \multicolumn{2}{|c|}{ Rata-rata Kelas } & \multicolumn{3}{|c|}{77,65} \\
\hline
\end{tabular}

Keterangan:
L: Laki-laki
P: Perempuan

Berdasarkan data hasil penelitian siklus II tersebut, kemampuan menulis teks berita siswa kelas VIII-A mendapat 26 siswa yang tuntas dan 8 siswa yang belum tuntas dalam pembelajaran menulis teks berita. Dari penilaian hasil data tersebut dinyatakan bahwa kemampuan menulis teks berita siswa memuaskan karena telah sesuai dengan keberhasilan target pada KKM (Kriteria Ketuntasan Minimal) $\geq 75 \%$ dan KKK (Kriteria Ketuntasan Klasikal) $75 \%$ dari jumlah siswa.

Kemudian dilihat dari data observasi terhadap tes kemampuan menulis teks berita tersebut dinyatakan bahwa kelas VIII-A SMP Swasta Imelda Medan persentase ketuntasan klasikal siswa mencapai 76,5\% yakni 26 siswa yang tuntas dan tidak tuntas klasikal siswa mencapai $23,5 \%$ yakni 8 siswa yang tidak tuntas dalam pembelajaran peningkatan menulis teks berita. Adapun rangkuman hasil data pelaksanaan observasi siklus II yang berupa hasil penilaian tes awal kemampuan tes berita terangkum dalam Tabel 6 . 
Tabel 6

\section{Perolehan Siklus II Tes Kemampuan Menulis Teks Berita Kasus Dugaan Pengeroyokan Siswi SMP}

\begin{tabular}{|c|c|c|}
\hline $\begin{array}{c}\text { Rentang } \\
\text { Nilai }\end{array}$ & Banyak Siswa & $\begin{array}{r}\text { Nilai Presentasi KKK Menulis Teks Berita } \\
\text { Potret Pendidikan di Indonesia }\end{array}$ \\
\hline $90-100$ & - & \multirow{2}{*}{$\begin{array}{c}76,5 \% \\
\text { Tinggi }(\leq 75 \%)\end{array}$} \\
\hline $80-89$ & 18 & $\begin{array}{r}\text { Lihat Tabel 3.4 "Kriteria Tingkat Keberhasilan } \\
\text { Belajar Siswa, halaman 44 }\end{array}$ \\
\hline $70-79$ & 8 & \\
\hline$\leq 69$ & 8 & 34
\end{tabular}

Siswa mendapatkan presentase kriteria ketuntasann klasikal 76,5\% pada siklus II karena siswa dapat memahami cara penulisan teks berita dengan baik dan benar. Siswa tidak takut untuk memberikan tenggapan mereka. Penerapan media video pembelajaran menulis teks berita pada siklus II ini sangat membuat mereka senang, karena mereka telah mengerti materi yang telah disampaikan oleh guru dan video berita yang dipaparkan tentang kasus dugaan pengeroyokan siswi SMP sedang banyak diperbincangkan pada media maupun masyarakat sehingga menimbulkan minat siswa dalam belajar. Maka, dapat disimpulkan nilai presentasi KKK kemampuan menulis adalah tinggi

Pada rangkuman nilai data siklus II tersebut dinyatakan bahwa tidak ada siswa dengan rentang nilai 90-100, 18 siswa dengan rentang nilai 80-89, 8 siswa dengan rentang nilai 7079 , dan 8 siswa dengan nilai $\leq 69$.

Adapun bukti data peningkatan nilai hasil pembelajaran menulis teks berita siswa siklus I dan siklus II dari tes yang telah diberikan pada akhir proses pembelajaran ditiap siklusnya dapat dilihat dalam rangkuman hasil penilaian kemampuan menulis teks berita siswa Tabel 7. 
Tabel 7

\section{Rekapitulasi Peningkatan Hasil Nilai Tes Kemampuan Menulis Teks Berita Pada} Siswa di Kelas VIII-A Pada Siklus I dan Siklus II

\begin{tabular}{|l|c|c|}
\hline \multicolumn{1}{|c|}{ Rentang Nilai } & Siklus I & Siklus II \\
\hline $90-100$ & - & - \\
\hline $80-89$ & 7 & 18 \\
\hline $70-79$ & 14 & 8 \\
\hline$\leq 69$ & 34 & 8 \\
\hline$\sum$ Siswa Kelas VIII-A & 2361 & 2640 \\
\hline Nilai Rata-rata Siswa Kelas VIII-A & 87 & 89 \\
\hline Nilai Tertinggi & 60 & 65 \\
\hline Nilai Terendah & $61,8 \%$ & $76,5 \%$ \\
\hline Persentase Ketuntasan Klasikal & $38,2 \%$ & $23,5 \%$ \\
\hline Persentase Yang Tidak Tuntas & & \\
\hline
\end{tabular}

Pada proses pembelajaran siklus I dan siklus II yang telah dilaksanakan dengan menerapkan media video pembelajaran meningkatkan menulis teks berita siswa yang bertujuan untuk melakukan perbaikan dari kondisi awal siswa pada kegiatan pembelajaran siklus I, Adapun hasilnya pada kegiatan pembelajaran siklus I yang peneliti lakukan di kelas VIII-A memperoleh nilai rata-rata keseluruhan siswa hanya mencapai 69,4 sebagaimana siswa yang lulus mendapatkan standar KKM $\geq 75$ hanya 21 siswa $(61,8 \%)$. Sedangkan siswa yang belum lulus mendapatkan nilai $\leq 69$ ada 13 siswa $(38,2 \%)$. Pada proses siklus I indikator keberhasilan pada penilaian ketuntasan klasikal siswa belum sesuai atau melampaui $\geq 75 \%$ sehingga dapat disimpulkan belum tercapai.

Berdasarkan penelitian yang telah dilakukan bahwa proses pembelajaran yang menerapkan medi video pembelajaran dapat meningkatkan menulis teks berita siswa kelas VIIIA . Oleh karena itu, media pembelajaran video pada mata pelajaran Bahasa Indonesia dapat berperan penting untuk meningkatkan menulis teks berita siswa apalagi media video tentang teks berita dapat memberikan kesempatan kepada siswa untuk mengulang pembelajaran yang belum dipahaminya. Selain itu, media pembelajaran video dapat melatih diri siswa untuk belajar mandiri sehingga semakin leluasa memberikan pendapat atau gagasannya terkait materi ajar yang sedang berlangsung.

Oleh karena itu, proses pembelajaran Bahasa Indonesia yang menerapkan media video dapat meningkatkan kemampuan menulis teks berita siswa kelas VIII-A SMP Swasta Imelda Medan. 


\section{Pembahasan Penelitian}

Tahap tindakan yang telah dilakukan dalam penelitian ini adalah penerapan media video pembelajaran untuk meningkatkan menulis teks berita. Pemilihan media tersebut merupakan upaya untuk mengatasi permasalahan yang dihadapi guru dalam rangka meningkatkan keterampilan siswa dalam menulis sebuah teks khususnya teks berita.

Media video menjadikan siswa lebih aktif, mandiri, dan antusias saat proses pembelajaran berlangsung. Siswa dituntut untuk berkonsentrasi penuh saat menanggapi materi ajar teks berita. Siswa lebih berperan aktif saat peneliti yang beraktivitas sebagai guru memberikan kesempatan kepada siswa untuk berdiskusi dengan teman sebangkunya dan saat penerapan media video pembelajaran menulis teks berita telah bergilir untuk proses panggilan pemahaman siswa dari apa yang telah dipahaminya terkait berita yang telah dipaparkan.

Media pembelajaran ini lebih menekankan peran siswa dalam pembelajaran, peneliti hanya berperan sebagai fasilitator dalam pembelajaran seperti mengondisikan keadaan pembelajaran yang sedang berlangsung di kelas. Siswa menemukan pengertian menulis teks berit, memahami isi dan unsur-unsur berita yang telah dipaparkan, hingga hasil akhirnya dapat dilihat hasilnya dari penilaian pengerjaan tes kemampuan menulis teks berita disetiap akhir siklus pembelajaran.

Terlihat dari hasil di siklus I dan siklus II meningkat sesuai dengan Kriteria Ketuntasan Minimal $(\mathrm{KKM}) \geq 75$ dan nilai persentase Ketuntasan Klasikal siswa dengan nilai $\geq 75 \%$. Dengan demikian, dapat disimpulkan bahwa berdasarkan rumusan masalah dan hipotesis tindakan telah dipaparkan pada hasil penelitian di ini, dalam menerapkan penggunaan media video dapat meningkatkan kemampuan menulis teks berita siswa kelas VIII-A SMP Swasta Imelda Medan dalam hal tersebut dapat membantu guru bidang studi Bahasa Indonesia untuk lebih aktif lagi dalam mengelola kondisi kelas.

\section{SIMPULAN} berikut.

Berdasarkan hasil dan pembahasan dalam penelitian ini dapat disimpulkan sebagai

1. Proses penggunaan media video untuk meningkatkan kemampuan menulis teks berita siswa kelas VIII-A SMP Swasta Imelda Medan tahun pelajaran 2018/2019. Dengan penerapan penggunaan media video dalam pembelajaran menulis teks berita yang diberikan pada siklus I dan siklus II dapat meningkatkan hasil belajar siswa.

2. Hasil pembelajaran menulis teks berita dengan menerapkan penggunaan media video dalam pembelajaran pada siswa kelas VIII-A SMP Swasta Imelda Medan tahun pelajaran 2018/2019, pada siklus I ketuntasan klasikal 61,8\%, dan nilai rata-rata siswa mencapai 69,4 pada siklus II media video dapat meningkatkan kemampuan menulis teks berita siswa dengan perolehan nilai rata-rata siswa yang mencapai 77,65 dan presentase ketuntasan kalsikal siswa memperoleh 76,5\%.

3. Adanya peningkatan hasil pembelajaran menulis teks berita dengan menerapkan penggunaan media video menulis teks berita pada siswa kelas VIII-A SMP Swasta Imelda Medan tahun pelajaran 2018/2019. Terbukti dari hasil penelitian nilai rata-rata siklus I 69, dan meningkat kembali nilai rata-rata siklus II 77,65. 


\section{DAFTAR PUSTAKA}

Arikunto. 2016. Prosedur penelitian suatu pendekatan praktik. Jakarta: PT. Rineka Cipta

Daryanto. 2012. Keterampilan menulis. Jakarta: PT. Raja Grafindo Persada.

Ernawati, Oki \& Utami Santi. 2017. Keefektivan pembelajaran menulis kreatif puisi Menggunakan Teknik Akrostik dan Teknik Latihan Bimbingan dengan Media Vidio Keindahan Alam untuk Siswa Kelas VII SMP Negeri 22 Semarang. Jurnal: Pendidikan Bahasa Dan Sastra Indonesia, vol.6. No. 2. https://jornal.unnes.ac.id.

Fitma Tiara, Gani Erizal \& Arief. 2017. Pengaruh Penggunaan Model Pembelajaran Problem Based Learning terhadap Keterampilan Menulis Teks Cerita Fabel Siswa Kelas VII SMP Negeri 4 Payukumbuh. Jurnal: Pendidikan Bahasa dan Sastra Indonesia, vol. 6. No. 2. http://ejournal.unp.ac.id

Hamdayana, Jumanto. 2014. Model dan Metode Pembelajaran Kreatif dan Berkarakter. Bogor: Ghalia Indonesia.

Istarani. 2015. 58 Model Pembelajaran Inovatif. Medan: Media Persada.

Ngalimun. 2015. Strategi dan Model Pembelajaran. Yogyakarta: Aswaja Pressindo.

Rahmawati. 2007. Meningkatkan Keterampilan Menulis Teks Berita melalui Teknik Pengamatan Gambar pada Siswa Kelas VIII-1 SMP Negeri 1 Batang Pati, vol. 5. No. 3. https://jornal.unnes.ac.id.

Rusman. 2016. Model-model Pembelajaran. Jakarta: Raja Grafindo Persada..

Shoimin Aris. 2106. 68 Model Pembelajaran Inovatif dalam Kurikulum 2013.Yogyakarta: ArRuzz Media.

Sugiyono. 2016. Metode Penelitian-Kuantitatif, kualitatif dan R\&D. Bandung: Alfabeta.

Zabadi Fairul, Hasanuddin, dkk. 2014. Bahasa Indonesia Wahana Pengetahuan. Jakarta: Kementrian Pendidikan dan Kebudayaan. 